\title{
IDENTIFICATION OF 4-O-METHYL-D-XYLOSE AS A CONSTITUENT OF THE CELL WALL OF CHLORELLA VULGARIS
}

\section{BERNHARD BRUNNER and ECKHARD LOOS}

Institut für Botanik, Universität Regensburg, Universitätsstrasse 31, D-8400 Regensburg (F.R.G.)

(Received June 13th, 1985)

(Revision received August 26th, 1985)

(Accepted October 1st, 1985)

From the cell wall of a strain of Chlorella vulgaris a sugar was isolated after acid hydrolysis and was identified as 4-O-methyl-D-xylose by the following criteria: (i) mass spectroscopy of its alditol acetate revealed characteristic primary fragments with $m / e 117$ and $m / e$ 261, and, when one deuterium atom was substituted at $\mathrm{C}-1$, with $m / e 262$ instead of $m / e$ 261; (ii) after demethylation with $\mathrm{BCl}_{3}$, xylose was identified as its parent sugar by chromatographic methods; (iii) L-iditol: NAD 5-oxidoreductase (sorbitol dehydrogenase) catalyzed the oxidation of its alditol, but not of 4-O-methyl-L-xylitol. 4-O-Methyl-D-xylose amounted to approx. $10 \%$ of the cell walls' dry weight or $1.6 \%$ of the cells' dry weight.

Key words: cell wall; Chlorella; 4-O-methyl-D-xylose

\section{Introduction}

In an investigation of the cell wall composition of chlorococcal algae, an unidentified sugar was found in wall hydrolysates of several strains of Chlorella [1]. In one strain (C. vulgaris $\dot{\mathrm{K}}$ ), it amounted to $10 \%$ of the cell walls' dry weight and to $13 \%$ of the total neutral sugars, whereas in the other strains it was present in trace amounts only. The goal of this work was to clarify the structure of this sugar. Its occurrence in nature is briefly reviewed.

\section{Materials and methods}

C. vulgaris strain $\mathrm{K}$ was obtained from $\mathrm{Dr}$. N. Sauer in our institute. The algae were grown in a mineral medium [2] under continuous illumination $(7.5 \mathrm{klx})$ and harvested after 3 days. Other conditions of culture and isolation of cell walls have been described previously [3].

Hydrolysis of the cell walls was carried out in $2 \mathrm{M}$ trifluoroacetic acid at $100^{\circ} \mathrm{C}$ for
$2 \mathrm{~h}$; the insoluble material was removed by centrifugation and trifluoroacetic acid by evaporation under reduced pressure.

\section{Paper and thin-layer chromatography}

For preparative paper chromatography, Whatman paper No. $3 \mathrm{M}$ was used; for analytical thin-layer chromatography, aluminum sheets coated with cellulose or silica gel were employed (Merck, Darmstadt, F.R.G.). The following solvent systems were used (v/v): (I) $n$-BuOH/EtOH $/ \mathrm{H}_{2} \mathrm{O}$ with $1 \% \mathrm{NH}_{3}=$ $4: 1: 5$ (upper phase); (II). $n-\mathrm{BuOH} /$ pyridine/ $\mathrm{H}_{2} \mathrm{O}=10: 3: 3$; (III) $n-\mathrm{BuOH} / \mathrm{EtOH} / \mathrm{H}_{2} \mathrm{O}$ $=40: 11: 19 ;(\mathrm{IV})$ Isopropanol $/ \mathrm{H}_{2} \mathrm{O}=8: 2(\mathrm{~V})$ acetone $/ n-\mathrm{BuOH} / \mathrm{H}_{2} \mathrm{O}=70: 15: 15$. System I was used for descending paper chromatography, systems I-III for cellulose thin layers and system IV and V with the silica gel layers; for system IV the silica gel layer was prerun in $\mathrm{Na}_{2} \mathrm{~B}_{4} \mathrm{O}_{7}\left(50 \mathrm{mmol} \cdot \mathrm{l}^{-1}\right)$ and dried before use. For preparative thinlayer chromatography, glass plates were coated with a slurry of silica gel $(50 \%, w / v)$ 
in $\mathrm{Na}_{2} \mathrm{~B}_{4} \mathrm{O}_{7}\left(0.1 \mathrm{~mol} \cdot \mathrm{l}^{-1}\right)$ yielding a layer of $1 \mathrm{~mm}$ thickness and were run in solvent system IV. Staining for sugars was done on the silica gel layers with a diphenylamine/ aniline based reagent or with alkaline $\mathrm{KMnO}_{4}$, and, on cellulose layers or paper with alkaline $\mathrm{AgNO}_{3}$.

\section{Isolation of the unknown sugar}

The unknown sugar was prepared by chromatography of cell wall hydrolysates either on paper or on $\mathrm{Na}_{2} \mathrm{~B}_{4} \mathrm{O}_{7}$-impregnated silica gel. In both cases the region giving a sugar stain in front of rhamnose was eluted and, if necessary, desalted by a mixed bed ion exchange resin (Amberlite MB 3, Merck, Darmstadt, F.R.G.).

Preparation of alditol acetates and analysis by gas liquid chromatography.

The monosaccharide material $(0.3-1 \mathrm{mg})$ was reduced with $0.5 \mathrm{mg} \mathrm{NaBH}$ for several hours at room temperature in a total volume of $0.25 \mathrm{ml}$; the $\mathrm{pH}$-value (adjusted with $\mathrm{NaOH}$ ) was between 8 and 9 . The further procedures were performed essentially according to Albersheim et al. [4]. After acetylation the excess acetic anhydride was removed by evaporation in a nitrogen stream, $3 \mathrm{ml}$ dichloromethane and $1.5 \mathrm{ml} \mathrm{H}_{2} \mathrm{O}$ were added and, after shaking and centrifugation, the water phase was discarded; this washing with water was repeated twice. The dichloromethane phase was evaporated in a nitrogen stream and the residue was dissolved in $0.1-0.4 \mathrm{ml}$ acetone. For gas liquid chromatography $1 \mu \mathrm{l}$ of this solution was injected into a Hewlett Packard 5830 A gas chromatograph on a column $(1.8 \mathrm{~m} \times 2 \mathrm{~mm})$ filled with $3 \%$ SP-2340 on Supelcoport 100/120 (Supelco). Nitrogen was the carrier gas (28 $\mathrm{ml} / \mathrm{min}$ ) and a temperature program of $190^{\circ} \mathrm{C}-225^{\circ} \mathrm{C}$ at $2^{\circ} \mathrm{C} / \mathrm{min}$ was run. Inositol was used as internal standard.

\section{Mass spectroscopy}

The sugars were transformed to their alditol acetates and analyzed in a combined gas liquid chromatograph/mass spectrometer (Hewlett Packard, Type 5995) with a quartz capillary column (30 m; type Durabond 1701; ICT-Laboratories, Frankfurt, F.R.G.) which was heated from $140^{\circ} \mathrm{C}$ to $220^{\circ} \mathrm{C}$ $\left(2^{\circ} \mathrm{C} / \mathrm{min}\right)$; the carrier gas was helium $(1 \mathrm{ml} /$ $\min )$. The interphase temperature was $280^{\circ} \mathrm{C}$. Fragments occurring in the range between 40 and 400 mass units were registered.

\section{Demethylation}

Demethylation was carried out similar to the procedure of Bonner et al. [5]. After removal of $\mathrm{CH}_{2} \mathrm{Cl}_{2}$ and $\mathrm{BCl}_{3}$ the sample was taken up in water to hydrolyze the sugar- $\mathrm{BCl}_{3}$ complex and evaporated under reduced pressure. After repeated addition of methanol containing $1 \%$ acetic acid and evaporation in a nitrogen stream, the sample was dissolved in water and desalted with Amberlite MB 3 ion exchange resin.

\section{Enzymatic assays}

L-Iditol dehydrogenase and L-lactate dehydrogenase were purchased from Boehringer, Mannheim, F.R.G. The sugar alcohol 4-Omethyl-L-xylitol (being identical with 2-Omethyl-D-xylitol) was prepared by reduction of 2-O-methyl-D-xylose (Sigma, St. Louis, U.S.A.) with $\mathrm{NaBH}_{4}$; 4-O-methylxylitol from Chlorella was also obtained by reduction with $\mathrm{NaBH}_{4}$. All assays were carried out at $22 \pm 1^{\circ} \mathrm{C}$.

\section{Results and discussion}

Identification of the unknown sugar as 4-O-methyl-D-xylose

When hydrolysates of isolated cell walls were separated by paper chromatography and stained for sugars, besides the spots corresponding to rhamnose, galactose and xylose a component was encountered running ahead of rhamnose. Upon elution and rechromatography in the thin-layer systems $\mathrm{I}-\mathrm{V}$ this component moved as one spot having an $R_{f}$-value greater than that of rhamnose; this was especially pronounced in 
system IV, where its $R_{f}$-value was 0.48 and that of rhamnose 0.29 . Gas liquid chromatography of its alditol acetate revealed a uniform peak; as a contaminant only rhamnose was detected in significant arnounts (4-5\%). Samples obtained by preparative thin-layer chromatography contained less than $1 \%$ impurities. The yield of the unknown sugar component was $3.9 \mathrm{mg}$ from $1 \mathrm{ml}$ packed cells; this is equivalent to $1.6 \%$ of the cells' dry weight or $9.7 \%$ of the cell wall [cf. 1]. Mass spectroscopy of the alditol acetate revealed conspicuous fragments with $m / e 117$ and 43 and other fragments, each of which occurred with an abundance below $16 \%$ (Table IA). As primary fragments char-

Table I. Mass spectroscopic data of the alditol acetate of a sugar from the cell wall of Chlorella. In the reduction step to the alditol, $\mathrm{NaBH}_{4}$ (A) or $\mathrm{NaBD}_{4}$ (B) was used.

\begin{tabular}{llll}
\hline$m / e$ & $\begin{array}{l}\text { Abundance } \\
(\%)\end{array}$ & $m / e$ & $\begin{array}{l}\text { Abundance } \\
(\%)\end{array}$
\end{tabular}

\begin{tabular}{lrrr}
\hline$A$ & & & \\
41.30 & 2.6 & 87.05 & 6.3 \\
43.10 & 95.2 & 99.05 & 10.3 \\
44.00 & 6.0 & 100.05 & 2.6 \\
45.20 & 2.0 & 103.00 & 4.0 \\
49.30 & 2.4 & 113.10 & 4.0 \\
54.20 & 2.2 & 115.10 & 6.5 \\
55.30 & 2.2 & 117.10 & 100.0 \\
58.00 & 6.5 & 118.10 & 7.1 \\
59.10 & 2.4 & 127.10 & 14.1 \\
69.15 & 2.4 & 129.00 & 4.4 \\
70.85 & 2.4 & 130.10 & 3.8 \\
74.15 & 3.0 & 159.15 & 6.0 \\
74.95 & 2.6 & 172.10 & 3.2 \\
81.05 & 2.6 & 201.10 & 3.6 \\
85.05 & 15.7 & 261.20 & 3.0 \\
86.05 & 2.8 & & \\
$B$ & & & \\
41.25 & 2.8 & 87.10 & 7.9 \\
43.15 & 88.8 & 99.10 & 3.4 \\
44.05 & 5.1 & 100.10 & 8.4 \\
45.05 & 2.2 & 117.15 & 100.0 \\
57.15 & 2.2 & 118.05 & 9.6 \\
58.05 & 8.4 & 128.15 & 16.9 \\
59.05 & 2.8 & 159.10 & 6.2 \\
74.05 & 3.9 & 173.10 & 3.9 \\
85.20 & 3.4 & 202.15 & 3.4 \\
86.10 & 11.2 & 262.20 & 2.2 \\
\hline
\end{tabular}

acteristic for a peracetylated 2-O-methylor 4-O-methylpentitol were considered those with $m / e \quad 117$ and 261. These originate from the preferred breakage of the carbon chain in vicinity of the methoxylated $\mathrm{C}$ atom $[6,7]$. This is illustrated for peracetylated 2-O-methyl- or 4-O-methylxylitol in Scheme I.<smiles>CC(=O)OCC(C)C(OC(C)=O)C(C)C(C)C(C)C(C)OC(C)=O</smiles>

I

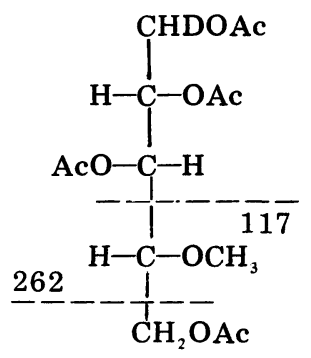

II
To differentiate between a pentose substituted in 2- or 4-position, the reduction step to the alditol was carried out with $\mathrm{NaBD}_{4}$. The dominant primary fragment obtained then was also $m / e 117$, whereas the fragment $m / e 261$ was substituted by $m / e$ 262 (Table IB). This pattern is evidence for the presence of a 4-O-methylpentose (cf. Scheme II; [8]). A control experiment with authentic 2-O-methylxylose gave characteristic primary fragments of $m / e 117$ and 261 with $\mathrm{NaBH}_{4}$ as reducing agent, and of $m / e 118$ and 261 when $\mathrm{NaBD}_{4}$ was used instead.

To obtain the parent sugar of the 4-Omethylpentose, demethylation with $\mathrm{BCl}_{3}$ [cf. 5] was carried out. Thin-layer chromatography of the reaction product gave a single spot at the position of xylose with solvent system I and V; in gas liquid chromatography one prominent peak eluted having the retention time of xylose. The unknown sugar, therefore, is believed to be a 4-O-methylxylose.

Its steric configuration was determined with L-iditol dehydrogenase (sorbitol dehydrogenase). This enzyme stereospecifically catalyzes the $\mathrm{NAD}^{+}$-dependent oxidation 


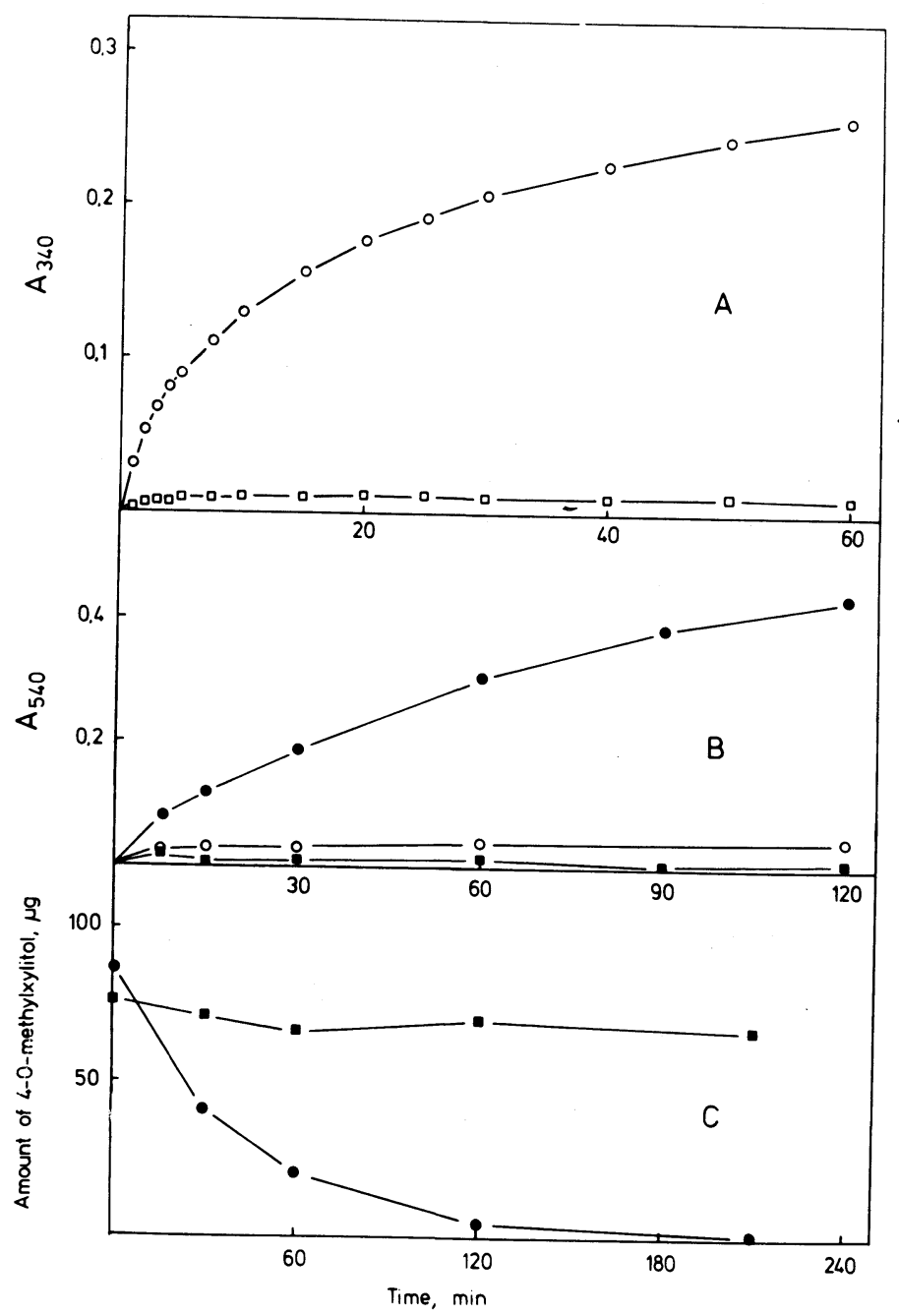

Fig. 1. A: Kinetics of NADH formation catalyzed by L-iditol dehydrogenase with 4-O-methylxylitol derived from Chlorella cell walls $(\circ-\circ)$ and with $4-O$-methyl-L-xylitol $(\square-\square)$ as substrates. The concentrations in mmol $\cdot 1^{-1}$ were: $\mathrm{NAD}^{+}, 1.0 ; 4-O$-methyl-xylitols, $1.0 ; \mathrm{Na}_{2} \mathrm{HPO}_{4} / \mathrm{KH}_{2} \mathrm{PO}_{4}$ buffer $(\mathrm{pH} \mathrm{7.4}), 25.0$. The reaction was started by adding L-iditol dehydrogenase to yield a final concentration of 0.8 units $\cdot \mathrm{ml}^{-1}$. B: Kinetics of ketose formation catalyzed by L-iditol dehydrogenase with 4-O-methylxylitol derived from Chlorella cell walls ( $-\circ$; $\bullet-(-)$ and with 4-O-methyl-L-xylitol as substrates (-—). The filled symbols indicate the presence of 2.0 $\mathrm{mmol} \cdot \mathrm{l}^{-1}$ pyruvate and 2.8 units $\cdot \mathrm{ml}^{-1}$ lactate dehydrogenase; other concentrations as in Fig. $1 \mathrm{~A}$. Samples of $100 \mu \mathrm{l}$ were used for the ketose assay with cysteine/sulfuric acid/carbazole according to Dische [10]. C: Kinetics of disappearance of $4-O$-methylxylitol derived from Chlorella cell walls $(\bullet-\bullet)$ and of 4-O-methyl-Lxylitol (- ). The reaction was started by addition of L-iditol dehydrogenase $\left(1.6\right.$ units $\left.\cdot \mathrm{ml}^{-1}\right)$; the concentrations of the other components was as in Fig. $1 \mathrm{~A}$ except that pyruvate $\left(2.0 \mathrm{mmol} \cdot \mathrm{l}^{-1}\right)$ and lactate dehydrogenase $\left(2.8\right.$ units $\left.\cdot \mathrm{ml}^{-1}\right)$ were included. Samples of $0.5 \mathrm{ml}$ were taken and kept for $3 \mathrm{~min}$ at $100^{\circ} \mathrm{C}$ to stop the reaction; 4-O-methylxylitol was determined as its peracetylated derivative by gas liquid chromatography with inositol as internal standard. 
of polyols having the structural feature $\mathrm{A}$ [cf. 9]; the reaction product is a ketose.<smiles>CC(O)C(O)C(O)CO</smiles>

A<smiles>COC(CO)C(O)C(O)CO</smiles>

B<smiles>COC(CO)C(O)C(O)CO</smiles>

C
Because of the steric relationship this reaction is also expected with 4-O-methylD-xylitol (B), but not with its enantiomer (C).

When 4-O-methylxylitol derived from the 4-O-methylxylose of Chlorella was incubated with L-iditol dehydrogenase and $\mathrm{NAD}^{+}$, formation of NADH was observed, which, however, was negligible in the control with 4-O-methyl-L-xylitol (Fig. 1A). The formation of ketose was seen with the 4-O-methylxylitol in question and was quite conspicuous when the equilibrium, which is in favor of the sugar alcohol, was shifted by removing NADH via pyruvate plus lactate dehydrogenase (Fig. 1B). With this system after prolonged incubation almost all of the 4-Omethylxylose was converted (Fig. 1C). With 4-O-methyl-L-xylitol as substrate, no significant ketose formation was detected (Fig. 1B). It is concluded from these experiments that the 4-O-methylxylose of the Chlorella cell wall belongs to the $\mathrm{D}$-series.

\section{Occurrence of 4-O-methylxylose in nature}

The methyl sugar 4-O-methylxylose has been found in the wood of chestnut (Castanea sativa) [11], in the lipopolysaccharide of Rhodopseudomonas palustris [8] and in flagellar glycoconjugates of Chlamydomonas eugametos [12]. In the strain of Chlorella used here, 4-O-methylxylose constituted approx. $10 \%$ of the cell wall or $1.6 \%$ of the cell dry weight. This $(1.6 \%)$ is a 30 - to 100 fold higher content than in Castanea [11] and in Rhodopseudomonas [8,13]. For Rhodopseudomonas, 4-O-methylxylose is discussed as a component of the polysaccharide chain responsible for the $O$-specificity [8]; in Chlamydomonas, the presence of 4-Omethylxylose and certain other sugars seems to determine the mating type [12]. A specific function of this methyl sugar in Chlorella, however, cannot be envisaged yet.

\section{Acknowledgements}

Thanks are due to Dr. H. Mayer and Dr. F. Wieland for help with the mass spectra and to D. Meindl for technical assistance. This work was supported by the Deutsche Forschungsgemeinschaft.

\section{References}

1 M. Blumreisinger, D. Meindl and E. Loos, Phytochemistry, 22 (1983) 1603.

2 A. Kuhl, Zur Physiology der Speicherung kondensierter anorganischer Phosphate in Chlorella, in: Beiträge zur Physiologie und Morphologie der Algen, Deutsche Botanische Gesellschaft (Ed.), Fischer, Stuttgart, 1962, p. 157.

3 E. Loos and D. Meindl, Planta, 156 (1982) 270.

- 4 P. Albersheim, D.J. Nevins, P.D. English and A. Karr, Carbohydr. Res., 5 (1967) 340.

5 T.G. Bonner, E.J. Bourne and S. McNally, J. Chem. Soc., (1960) 2929.

6 H. Björndal, B. Lindberg and S. Svensson, Carbohydr. Res., 5 (1967) 433.

7 H. Björndal, B. Lindberg and S. Svensson, Carbohydr. Res., 5 (1967) 433.

8 J. Weckesser, H. Mayer and J. Fromme, Biochem. J., 135 (1973) 293.

9 M.G. Smith, Biochem. J., 83 (1962) 135.

10 Z. Dische, Color Reaction of Ketoses with Carbazole and Sulfuric acid, in: Methods in Carbohydrate Chemistry, R.L. Whistler and M.L. Wolfrom (Eds.), Vol. 1, Academic Press, New York and London, 162, p. 481.

11 A. Roudier and H. Gillet, Rev. Ass. Tech. Ind. Papet., 21 (1967) 295.

12 G.J. Gerwig, J.P. Kamerling and J.F.G. Vliegenthart, W.L. Homann, P. van Egnond and H. van den Ende, Carbohydr. Res., 127 (1984) 245.

13 J. Weckesser, G. Drews, J. Fromme and H. Mayer, Arch. Microbiol., 92 (1973) 123. 